\title{
Deformability of Red Blood Cells and Correlation with ATP Content during Storage as Leukocyte-Depleted Whole Blood
}

\author{
Ralf Karger Christian Lukow Volker Kretschmer
}

Institut für Transfusionsmedizin und Hämostaseologie, Klinikum der Philipps-Universität Marburg, Germany

\section{Keywords}

ATP content - Deformability · Quality .

Red cell storage $\cdot$ Storage lesion · In vivo survival .

Whole blood

\section{Summary}

Background: Storage duration of red cells has been associated with increased morbidity and mortality following transfusion. This association has been attributed to the loss of deformability of stored red cells leading to deterioration of microvascular perfusion. ATP content is considered a critical determinant of the deformability of stored red cells. Methods: ATP content and deformability were determined after storage for up to 49 days in 40 leukocyte-depleted whole blood units. Red cell deformability was determined using a laser-assisted optical rotational cell analyzer (LORCA ${ }^{\circledR}$ ) employing shear stress (SS) ranging from 0.3 to $30 \mathrm{~Pa}$. Deformability was expressed as the elongation index (EI). El was correlated with ATP content. Results: ATP content decreased from 3.5 to $1.7 \mu \mathrm{mol} / \mathrm{g}$ hemoglobin. El increased from 0.03 to 0.05 at an SS of $0.3 \mathrm{~Pa}$, and decreased from 0.62 to 0.59 at an SS of $30 \mathrm{~Pa}$. Correlation coefficient ( $r$ ) of ATP vs. EI at $0.3 \mathrm{~Pa}$ ranged from -0.17 to +0.15 during storage. At $30 \mathrm{~Pa}, r$ ranged from -0.03 to +0.45 . Correlation increased with storage irrespective of SS, and increased with SS irrespective of storage. Conclusions: ATP content is not a valid surrogate marker for red cell deformability and may not reflect in vivo survival of stored red cells.

\section{Schlüsselwörter \\ ATP-Gehalt · Verformbarkeit · Qualität . \\ Erythrozytenlagerung · Lagerungsschaden In-vivo- \\ Überleben · Vollblut}

\section{Zusammenfassung}

Hintergrund: Die Hinweise mehren sich, dass die Lagerungsdauer von Erythrozyten mit einer erhöhten Morbidität und Mortalität nach einer Transfusion assoziiert ist. Für diesen Zusammenhang werden die verminderte Flexibilität gelagerter Erythrozyten und eine damit einhergehende Verschlechterung der mikrovaskulären Perfusion verantwortlich gemacht. Der ATP-Gehalt wird als kritische Determinante der Verformbarkeit gelagerter Erythrozyten angesehen. Methoden: ATP-Gehalt und Erythrozytenverformbarkeit wurden über einen Lagerungszeitraum von 49 Tagen an 40 leukozytendepletierten Vollblutkonserven untersucht. Die Erythrozytenverformbarkeit wurde mit einem "laser-assisted-opticalrotational-cell-analyzer» (LORCA ${ }^{\circledR}$ ) über Scherstress (SS) von 0,3 bis $30 \mathrm{~Pa}$ als sogenannter Elongationsindex (EI) gemessen. Der El wurde mit dem ATP-Gehalt der Erythrozyten korreliert. Ergebnisse: Der ATP-Gehalt nahm von $3,5 \mu \mathrm{mol} / \mathrm{g}$ Hämoglobin auf 1,7 $\mu \mathrm{mol} / \mathrm{g}$ Hämoglobin ab. Der El stieg bei einem SS von 0,3 $\mathrm{Pa}$ von 0,03 auf 0,05, und nahm bei $30 \mathrm{~Pa}$ von 0,62 auf 0,59 ab. Der Korrelationskoeffizient $r$ (ATP vs. El) lag bei einem SS von 0,3 $\mathrm{Pa}$ zwischen $-0,17$ und $+0,15$ und bei $30 \mathrm{~Pa}$ zwischen $-0,03$ und $+0,45$. Die Korrelation nahm mit der Lagerungsdauer unabhängig vom SS und mit dem SS unabhängig von der Lagerungsdauer zu. Schlussfolgerungen: Der ATPGehalt ist kein valider Surrogatmarker für die Erythorzytenverformbarkeit und dürfte somit nicht das In-vivoÜberleben gelagerter Erythrozyten widerspiegeln. 


\section{Introduction}

The measurement of the ATP content of red cells during storage has become a routine approach for evaluating the storage lesions in red cells. The main concern, however, is not the storage lesion per se, but the integrity and viability of the red cells in the recipient's circulation. Storage lesions, basically characterized by a couple of biochemical markers, including the ATP content of the red cells, represent only a surrogate marker for the red cell's ability to survive in the recipient's circulation. As early as 1947, Rapoport had shown that there was a close association between the ATP content of stored red cells and their viability [1]. A fall in ATP content is usually associated with a shape change from discs to spheres, a loss of membrane lipid, and an increase in cellular rigidity. That the loss in ATP is actually the cause for the increased rigidity of the red cells has been inferred from the observation that restoring the ATP content of the red cells before transfusion restores their normal flexibility, and greatly enhances viability. Maintaining red cell integrity and flexibility is an energy-consuming process $[2,3]$. It is presumed that when ATP content is below a certain critical level, red cells lose their capacity to phosphorylate glucose and, therefore, to derive energy from it. However, the association between ATP content of the red cell and viability is only modest, suggesting that other processes independent of ATP content, like loss of membrane lipid, have a significant influence on red cell survival. Thus, the association between ATP content and red cell flexibility might not be as causal as sometimes presumed.

Several unfavorable effects of transfusion may be associated with storage lesions of the red cells in blood products [4]. There is increasing evidence of an association between the duration of storage and clinical outcome [5, 6], although a causal relationship has not yet been established [7-9]. Possible mechanisms explaining this association are the 2,3-diphosphoglycerate (2,3-DPG) deficiency of stored red cells, which results in a reduced capacity of the red cells to release oxygen to the tissues, and an increased rigidity of the red cells. This increased rigidity results in elevated adherence to endothelial cells [10], precluding them from readily passing small capillaries [11], and leading to increased vascular resistance [12]. Several randomized clinical trials are under way to clarify this issue [7]. Since red cell flexibility or deformability are major determinants of red cell viability [13], the aim of this study was to investigate, in addition to established biochemical markers, rheological properties of red cells at different shear rates in leukocyte-depleted whole blood over a 7-week storage period. This study is a post hoc analysis of a randomized experiment comparing different blood collection methods [14].

\section{Material and Methods}

\section{Blood Collection}

In this study, $2 \times 20$ leukocyte-depleted whole blood (LD-WB) units were investigated in a randomized controlled fashion [14]. In 1 group, an anticoagulant (citrate phosphate dextrose adenine 1; CPDA-1) was continuously added to $500 \mathrm{ml}$ donated whole blood via a roller pump attached to scales, using a new blood drawing device, the 'Automat for Blood Collection' (MacoPharma $\mathrm{ABC}^{\circledR}$, MacoPharma, Langen, Germany). In the comparison group blood was drawn using a conventional drawing device (Compomixer M2 ${ }^{\circledR}$, Fresenius HemoCare, Bad Homburg, Germany); for this the collection bag was prefilled with $70 \mathrm{ml} \mathrm{CPDA-1,} \mathrm{and} \mathrm{mixing} \mathrm{was}$ accomplished by automated tilting of the scales. All whole blood units were put on $4{ }^{\circ} \mathrm{C}$ cooling plates immediately after collection (Compo$\operatorname{cool}^{\circledR}$, Fresenius HemoCare) and were leukocyte-depleted $2 \mathrm{~h}$ post donation at room temperature using an in-line LST2 filter (MacoPharma). The study was approved by our institutional review board. The data from the 2 groups were pooled for this post hoc analysis.

\section{Laboratory Investigations}

Red cell quality parameters, i.e. ATP, 2,3-DPG, free hemoglobin, potassium, glucose, lactate, $\mathrm{pH}$, and parameters of plasma coagulation (prothrombin time (PT), activated partial thromboplastin time (aPTT), thrombin time (TT), fibrinogen, coagulation factors V and VIII (FV and FVIII), antithrombin (AT), D-dimer, thrombin-AT complexes (TAT)) were determined on days $1,7,21,35,42$, and 49 of storage. Samples were taken from all whole blood units after thorough but gentle mixing of the units. Except for ATP and 2,3-DPG measurements, parameters were determined in plasma/CPDA-1 supernatants after centrifugation of the samples. The ATP concentration was measured enzymatically using a commercial test kit (Rolf Greiner BioChemica, Flacht, Germany). Details of the different methods are reported elsewhere [14].

Red cell deformability was analyzed using a laser-assisted optical rotational cell analyzer $\left(\right.$ LORCA $\left.^{\circledR}\right)$ [15-17]. In brief, samples of the whole blood units were diluted 1:200 in polyvinylpyrolidone to generate a Newtonian fluid. The suspensions were then subjected to shear stress (SS), which was increased in 9 logarithmic steps from 0.3 to $30 \mathrm{~Pa}$, representing shear rates of $10-1,000 / \mathrm{s}$. This led to a change of the typical biconcave to an ellipsoid shape of the red cells, which could be visualized and quantified by means of the laser diffraction pattern. The elongation index (EI) was calculated as $\mathrm{EI}=(\mathrm{A}-\mathrm{B}) /(\mathrm{A}+\mathrm{B})$, where A represents the longer and $\mathrm{B}$ the shorter axis of the ellipsoid red blood cell. The EI is thought to be proportional to the deformability of the cells. To measure the aggregability, undiluted original samples were preincubated at $37{ }^{\circ} \mathrm{C}$ with air to obtain a hemoglobin ( $\mathrm{Hb})-\mathrm{O}_{2}$ saturation of $99-100 \%$. A shear rate of 500/s was then applied to the samples to achieve a complete disaggregation of red cells. Subsequently, shear force was stopped and the extent and kinetics of the spontaneous rouleaux formation of the red cells were measured by detecting the backscattered laser light. An aggregation index was calculated that describes the overall aggregation behavior of the cells. A higher aggregation index indicates higher aggregability, whereas $t_{1 / 2}$ (the time elapsing until peak intensity of the light signal is reduced by half) represents the velocity of the aggregation. The amplitude between maximum and minimum light intensity reflects the extent of the aggregation quantified in arbitrary units (au) $[15,16]$.

\section{Statistical Analysis}

Pearson's correlation coefficient $r$ was calculated for the correlation analyses [18]. Regression analyses were also performed to study the influence of covariates other than ATP content on deformability. All statistical tests were 2 -sided. p values $<0.05$ were considered statistically significant. 


\section{Results}

\section{Donors and LD-WB Units}

Donor characteristics and baseline blood product data are depicted in table 1 . All tested units contained less than $1 \times 10^{6}$ leukocytes per unit. Red cell and plasma quality parameters during storage are listed in table 2. Mean ATP content decreased from $3.5 \mu \mathrm{mol} / \mathrm{g} \mathrm{Hb}$ on day 1 to $1.7 \mu \mathrm{mol} / \mathrm{g} \mathrm{Hb}$ on day 49. A pronounced fall in ATP content was only observed from day 21 onwards. 2,3-DPG decreased during the first 2 weeks of storage to trough levels. These changes, as well as

Table 1. Donor demographics and blood product data $(n=40)$

\begin{tabular}{ll}
\hline Donors & \\
Sex, male/female & $20 / 20$ \\
Blood group, A/O & $20 / 20$ \\
Mean predonation Hb, mg/l (SD) & $149(12.0)$ \\
Median PT, \% (range) & $100(91-100)$ \\
Mean aPTT, s (SD) & $30.8(3.4)$ \\
Mean fibrinogen, g/l (SD) & $2.9(0.4)$ \\
LD-WB units & \\
Mean net volume, ml (SD) & $525(8.1)$ \\
Mean Hb content, g/unit (SD) & $66.7(6.6)$ \\
Median leukocytes, $10^{5} /$ unit (range) & $0.66(0.00-1.61)$ \\
\hline
\end{tabular}

$\mathrm{Hb}=$ Hemoglobin, $\mathrm{PT}=$ prothrombin time, aPTT $=$ activated partial thromboplastin time, LD-WB = leukocyte-depleted whole blood. hemolysis rate, potassium leak, glucose consumption and lactate production were similar to the changes usually observed during red cell storage. Except for FVIII activity, which fell to nearly a third of its initial value, the coagulation profile of the plasma supernatant showed only slight changes.

\section{Red Blood Cell Deformability and Aggregation (Table 3)}

Mean EI at an SS of $0.3 \mathrm{~Pa}$ increased from 0.03 on day 1 to 0.06 on day 49 ( $p<0.0001)$. At higher SSs, EI consistently decreased during storage, e.g. at an SS of $30 \mathrm{~Pa}$ from 0.62 on day 1 to 0.59 on day 49 ( $\mathrm{p}<0.0001)$. The magnitude of this decrease $(\triangle \mathrm{EI})$ was comparable for an SS of $1.7 \mathrm{~Pa}$ and above. A trend towards an increase of deformability during storage was only seen at the low SS of $0.3 \mathrm{~Pa}$. All aggregation parameters consistently showed a continuous decrease in aggregability, i.e. a tendency to rouleaux formation.

\section{Correlation Analyses (Table 4)}

Pearson's correlation coefficients $(r)$ of ATP vs. EI at $0.3 \mathrm{~Pa}$ SS ranged from -0.17 to +0.15 during storage. At $30 \mathrm{~Pa} \mathrm{SS}$, they ranged from -0.03 to +0.45 . In general, $r$ increased with storage irrespective of shear rates, and with higher shear rates irrespective of storage. When the analysis was not stratified by day of storage, $r$ was -0.26 at $0.3 \mathrm{~Pa} \mathrm{SS}$ and +0.75 at $30 \mathrm{~Pa}$ SS. Thus, time course had a significant influence of the relationship between ATP content and deformability, particularly at high SS, suggesting a typical example of a spurious correla-

Table 2. LD-WB quality parameters ${ }^{\mathrm{a}}$

\begin{tabular}{|c|c|c|c|c|c|c|}
\hline & \multicolumn{6}{|l|}{ Days of storage } \\
\hline & 1 & 7 & 21 & 35 & 42 & 49 \\
\hline \multicolumn{7}{|c|}{ Red cell storage parameters } \\
\hline ATP, $\mu \mathrm{mol} / \mathrm{g} \mathrm{Hb}$ & $3.5(0.4)$ & $3.8(0.4)$ & $3.5(0.4)$ & $2.7(0.4)$ & $2.3(0.4)$ & $1.7(0.4)$ \\
\hline 2,3-DPG, $\mu \mathrm{mol} / \mathrm{g} \mathrm{Hb}$ & $16.3(17.8)$ & $8.0(2.8)$ & $2.2(1.3)$ & $1.3(0.9)$ & $1.4(1.0)$ & $0.9(0.6)$ \\
\hline $\mathrm{K}^{+}$, mmol/unit & $1.4(0.11)$ & $3.8(0.38)$ & $6.5(0.59)$ & $8.5(0.59)$ & $9.2(0.72)$ & $10.0(0.74)$ \\
\hline Free hemoglobin, g/unit & $0.14(0.08)$ & $0.18(0.08)$ & $0.28(0.11)$ & $0.35(0.11)$ & $0.39(0.12)$ & $0.48(0.15)$ \\
\hline Hemolysis rate, $\%$ & $0.13(0.07)$ & $0.18(0.08)$ & $0.27(0.10)$ & $0.33(0.11)$ & $0.37(0.11)$ & $0.46(0.14)$ \\
\hline $\mathrm{pH}\left(22^{\circ} \mathrm{C}\right)$ & $7.3(0.11)$ & $7.2(0.08)$ & $7.0(0.08)$ & $6.8(0.06)$ & $6.8(0.06)$ & $6.7(0.05)$ \\
\hline Glucose, mg/dl & $429(20.1)$ & $386(19.1)$ & $307(31.7)$ & $262(30.0)$ & $237(31.2)$ & $217(34.5)$ \\
\hline Lactate, $\mathrm{mmol} / \mathrm{l}$ & $2.9(0.75)$ & $7.3(0.79)$ & $15.3(1.63)$ & $20.1(2.13)$ & $22.2(2.26)$ & $23.6(2.78)$ \\
\hline \multicolumn{7}{|c|}{ Plasma coagulation parameters } \\
\hline $\mathrm{PT}, \%$ & $90(8.1)$ & 89 (10.6) & $81(8.7)$ & $71(10.7)$ & 68 (12.6) & $66(14.2)$ \\
\hline aPTT, s & $36.4(4.1)$ & $40.2(4.9)$ & $40.9(5.7)$ & $41.7(6.2)$ & $41.6(6.5)$ & $41.8(7.1)$ \\
\hline $\mathrm{TT}, \mathrm{s}$ & $21.1(1.47)$ & $21.4(1.44)$ & $21.6(2.20)$ & $21.8(4.26)$ & $22.3(4.44)$ & $22.8(5.93)$ \\
\hline Fibrinogen, g/l & $2.4(0.36)$ & $2.4(0.36)$ & $2.4(0.39)$ & $2.4(0.42)$ & $2.4(0.42)$ & $2.5(0.44)$ \\
\hline $\mathrm{FV}, \%$ & $80(9.6)$ & $80(9.2)$ & $77(10.4)$ & $70(8.6)$ & $72(8.6)$ & $75(8.6)$ \\
\hline FVIII, \% & 89 (17.9) & $56(14.1)$ & $51(13.7)$ & $47(14.3)$ & $46(14.7)$ & $37(13.8)$ \\
\hline $\mathrm{AT}, \%$ & $92(10.1)$ & $94(10.0)$ & $90(9.6)$ & $91(10.3)$ & $90(9.5)$ & $87(9.8)$ \\
\hline D-dimer, $\mu \mathrm{g} / \mathrm{l}$ & $206(102)$ & $213(101)$ & 199 (99) & $229(100)$ & 237 (97) & $239(95)$ \\
\hline $\mathrm{TAT}, \mu \mathrm{g} / \mathrm{l}$ & $2.2(<2-7.1)$ & $2.2(<2-8.9)$ & $<2.0(<2-6.9)$ & $2.1(<2-7.9)$ & $2.3(<2-11.0)$ & $2.1(<2-10.2)$ \\
\hline
\end{tabular}


Table 3. LD-WB rheological properties ${ }^{\mathrm{a}}$

\begin{tabular}{|c|c|c|c|c|c|c|c|}
\hline & \multicolumn{7}{|c|}{ Red blood cell deformability and aggregation } \\
\hline & 1 & 7 & 21 & 35 & 42 & 49 & $\triangle \mathrm{EI}^{*}$ \\
\hline \multicolumn{8}{|l|}{$\mathrm{EI}$ at $\mathrm{SS}, \mathrm{Pa}$} \\
\hline 0.3 & $0.032(0.016)$ & $0.035(0.012)$ & $0.043(0.011)$ & $0.047(0.019)$ & $0.042(0.016)$ & $0.055(0.031)$ & +0.023 \\
\hline 0.5 & $0.064(0.015)$ & $0.063(0.012)$ & $0.063(0.012)$ & $0.056(0.012)$ & $0.053(0.011)$ & $0.053(0.011)$ & -0.011 \\
\hline 1.0 & $0.141(0.021)$ & $0.138(0.017)$ & $0.137(0.018)$ & $0.126(0.019)$ & $0.120(0.017)$ & $0.119(0.016)$ & -0.022 \\
\hline 3.0 & $0.361(0.019)$ & $0.354(0.014)$ & $0.351(0.015)$ & $0.337(0.017)$ & $0.331(0.015)$ & $0.325(0.016)$ & -0.036 \\
\hline 5.3 & $0.458(0.014)$ & $0.452(0.011)$ & $0.448(0.011)$ & $0.436(0.013)$ & $0.429(0.012)$ & $0.421(0.013)$ & -0.037 \\
\hline 9.5 & $0.528(0.011)$ & $0.524(0.009)$ & $0.521(0.008)$ & $0.511(0.009)$ & $0.505(0.009)$ & $0.497(0.010)$ & -0.031 \\
\hline 16.9 & $0.582(0.010)$ & $0.578(0.009)$ & $0.574(0.008)$ & $0.563(0.008)$ & $0.560(0.008)$ & $0.552(0.009)$ & -0.030 \\
\hline 30.0 & $0.621(0.008)$ & $0.618(0.008)$ & $0.613(0.007)$ & $0.606(0.007)$ & $0.599(0.008)$ & $0.591(0.008)$ & -0.030 \\
\hline Aggregation index & $38.9(10.4)$ & $36.7(8.2)$ & $35.9(7.0)$ & $34.9(6.7)$ & $34.5(6.5)$ & $33.3(6.6)$ &. \\
\hline Amplitude, au & $17.0(2.2)$ & $16.3(2.1)$ & $13.6(1.7)$ & $12.7(2.0)$ & $13.0(2.0)$ & $12.6(2.2)$ &. \\
\hline
\end{tabular}

Table 4. Correlations (Pearson's $r$ ) between ATP content and deformability (EI) at different SS

\begin{tabular}{llllllll}
\hline Days of storage & $\begin{array}{l}\text { All days } \\
\text { combined*** }\end{array}$ & 1 & 7 & 21 & 35 & 42 & 49 \\
\hline EI at SS, Pa & & & & & & & \\
0.3 & -0.262 & 0.068 & -0.016 & -0.171 & 0.015 & 0.149 & 0.098 \\
0.5 & 0.348 & 0.109 & 0.166 & 0.030 & 0.067 & 0.098 & 0.065 \\
1.0 & 0.435 & 0.099 & 0.221 & 0.116 & 0.107 & 0.113 & 0.112 \\
1.7 & 0.505 & 0.044 & 0.256 & 0.157 & 0.154 & 0.165 & 0.140 \\
3.0 & 0.589 & 0.011 & 0.264 & 0.185 & 0.198 & 0.204 & 0.210 \\
5.3 & 0.690 & 0.002 & 0.315 & 0.205 & 0.232 & 0.309 & $0.319 * *$ \\
9.5 & 0.734 & -0.000 & 0.258 & 0.202 & 0.170 & $0.404 *$ & $0.419 *$ \\
16.9 & 0.725 & -0.007 & 0.213 & 0.116 & 0.097 & $0.407 *$ & $0.434^{*}$ \\
30.0 & 0.753 & -0.029 & 0.216 & 0.103 & 0.126 & $0.397 * *$ & $0.454 *$ \\
\hline$* 0.01, * * \mathrm{p}<0.05, * * \mathrm{p}<0.0001$ for all coefficients. & & & & & \\
\hline
\end{tabular}

tion [18]. However, when we included the day of analysis as a variable into a regression model together with other covariates (study group, ATP content, 2,3-DPG, hemolysis rate, $\mathrm{pH}$, glucose, PT, FVIII activity, and aggregation index), after backward stepwise elimination of covariates, ATP content was the only covariate apart from day of analysis that contributed significantly to the variability of the EI (data not shown), particularly at high SS (5.3 $\mathrm{Pa}$ and above). The percentage of variability of EI explained by ATP content was still rather low, e.g. only $20 \%$ at $30 \mathrm{~Pa}$ SS on day $49\left(r^{2}=0.206\right)$.

\section{Discussion}

This is, to our knowledge, the first study formally analyzing the relationship between ATP content and deformability of stored red cells using state-of-the-art methodology. Our study demonstrates that a significant association between ATP con- tent and deformability only becomes apparent at high SS and when ATP content has decreased to less than $2.5 \mu \mathrm{mol} / \mathrm{g} \mathrm{Hb}$. However, most red cell concentrates nowadays have, at the end of their approved shelf life, ATP contents well above this threshold. Thus, there only seems to be an independent effect of ATP content on deformability at high SS, which is, however, most prominent only after 6 weeks of storage and only explains approximately $20 \%$ of the variability of deformability, at best. This statistical association is, therefore, of little clinical value. ATP content only slightly decreases during storage, and is too insensitive to indicate potentially relevant changes of red cell deformability. The ATP content of the red cells does not, therefore, reliably reflect red cell deformability at approved storage times. Similar results have been reported by others for LD red cell concentrates resuspended in saline adenine glucose mannitol (SAGM) [19].

The results of our study are in accordance with previous studies investigating deformability during storage. That red 
cells lose their deformability during storage has been consistently shown by indirect methods using filtration techniques [20] or the LORCA system [21]. Only the time course and the magnitude of the loss of deformability have differed between the studies, most likely for methodological reasons. The tendency of red cells to aggregate, i.e. their tendency for rouleaux formation by responding to rouleaugenic proteins, like fibrinogen, has been shown to increase in vivo with ageing of the red cells [22] and in vitro with storage time [23]. This is in contrast to the findings of our study where red cells exhibited a decrease in aggregability with storage time, most probably because the loss in deformability prevented rouleaux formation of the red cells. Alternatively, a growing number of non-biconcave-shaped red cells during storage could also explain the decrease in aggregability [24]. The discrepancy of our results to the former in vivo study might be easily explained by the fact that the mechanisms of aging in vivo appear to be quite different from the changes in stored red cells in vitro. In the latter in vitro study, increased aggregability with storage was only observed when red cells were resuspended in a dextran/ buffer solution or fresh allogeneic plasma, but not in autologous plasma. The authors concluded that the loss of fibrinogen of autologous plasma might have compensated the increase in aggregability, resulting in no change of aggregability in autologous plasma. Thus, according to the reasoning of the authors of this study, we should have observed an increase in aggregability since fibrinogen did not decrease during storage in our LD-WB units. In our view, this reasoning is very speculative and unsatisfying. We believe that methodological differences may explain the discrepant results of the 2 studies. Whereas in our study original whole blood samples were used, which were only re-oxygenated (see Material and Methods), in the other study, before investigating aggregability with an in-house method, the red cells were subjected to centrifugation and washing steps, which might have caused a number of artifacts.

Henkelman et al. [19] also used LORCA to study the aggregability and deformability in LD red cell concentrates in SAGM over a storage period of 7 weeks. In contrast to our study, aggregability did not drop steadily during storage, probably due to the low number of units investigated $(n=10)$, resulting in unstable estimates of the parameter values. Another explanation might be the difference in storage medium and hematocrit in comparison to our LD-WB units. Other studies have shown that the storage medium may have an influence on aggregability [25]. Furthermore, in addition to containing red cell membrane-stabilizing compounds, e.g. sorbitol or mannitol [26, 27], red cell concentrates lack a significant amount of plasma, which might also explain the observed differences.

In our study a consistent decrease in deformability during storage was found above an SS of $0.5 \mathrm{~Pa}$, and most prominently at SSs found in the microcirculation, i.e. around 3-5 Pa [28]. In contrast, the data of Henkelman et al. [19] show an inconsistent course of deformability at $3.9 \mathrm{~Pa}$, and a steady decrease only at $50 \mathrm{~Pa}$. This adds to the conflicting results observed by others $[25,29,30]$. Given that ATP only plays a small role in explaining the loss in deformability (see above), its decrease during storage might be attributed to the loss of Hb-bound nitric oxide, a variable that participates in controlling red cell deformation [31]. The discrepancies between the different studies might also be explained by the different storage media used for the red cells.

The results of our study are also in line with accumulating evidence that several changes other than a decrease in ATP content might play a bigger role in the deterioration of red cell function during storage. For example, the hemolysis occurring during storage has recently been proposed as a mechanism for endothelial injury and impaired vascular function [32]. Our data might also explain why studies investigating the association of ATP content with red cell viability have been conflicting [13].

Consequently, for state-of-the-art blood component preparations, ATP content measurement might imply an unsubstantiated sense of safety, resembling the fallible conclusions drawn from the investigations of surrogates or biomarkers in clinical research [33]. More sophisticated approaches, in particular including techniques that determine red cell deformability, are required to determine the in vivo quality of stored red cells since it is known that red cell deformability, i.e. the flexibility of the red cell membrane, is strongly related to normal red cell function and viability [13]. These methods, however, may need to be validated against the gold standard of red cell viability determination, i.e. radioactive ${ }^{51}$ Cr labeling [1].

There is still the need to prove that the loss of red cell function and viability is of such an importance that it causes unfavorable clinical outcomes. Observational studies showing an association between red cell storage and clinical outcome are usually biased [8] and are, therefore, unsuitable for establishing a causal relationship. An animal model of hemorrhagic shock could not provide proof of a causal role of prolonged storage for survival [34]. Such studies can only forego clinical trials in humans. Several randomized clinical trials are currently under way to clarify this issue, and their results are eagerly awaited [7].

A limitation of the present study might be that LD-WB units preserved in CPDA-1 were investigated. In most developed countries, LD red cell concentrates resuspended in additive solutions are the state-of-the-art red cell products for allogeneic transfusion. However, the results of this study are still valuable for autologous transfusion and the many clinical settings, particularly in developing countries [35] where allogeneic whole blood is still mainly employed. Furthermore, the use of whole blood is gaining renewed interest in developed countries [36-38] because it has been shown that leukocyte depletion results in a considerably improved plasma quality in whole blood [39]. 


\section{Conclusion}

Red cell ATP content is not a valid surrogate marker for red cell deformability, irrespective of the SS to which the red cells are subjected. This holds true even though ATP content and deformability of red cells do change significantly during storage. Deformability increases significantly at the SS found in the microcirculation. However, because this change is not likely to be biologically significant its clinical relevance is questionable.

\section{Acknowledgements}

We are indebted to all our donors who agreed to participate in this study. We would like to thank Mr. Benny Linder and Ms. Sonja Cappeller for their excellent technical assistance, our nurses for their committed care of our donors, and Dr. Frances C. Lucibello for her help with the preparation of the manuscript.

\section{Disclosure Statement}

The authors declare that they have no conflicts of interest relevant to this manuscript.

\section{References}

1 Klein HG, Anstee DJ: Mollison's Blood transfusion in Clinical Medicine, ed 11. Oxford, Blackwell Publishing, 2005.

2 Högman CF, Meryman HT: Storage parameters affecting red blood cell survival and function after transfusion. Transfus Med Rev 1999;13:275-296.

3 Cooke BM, Lim CT: Mechanical and adhesive properties of healthy and diseased red blood cells in Baskurt OK, Hardeman MR, Rampling MW, Meiselman HJ (eds): Handbook of Hemorheology and Hemodynamics. Amsterdam, IOS Press, 2007, pp 91-113.

4 Zubair AC: Clinical impact of blood storage lesions. Am J Hematol 2010;85:117-122.

$\checkmark 5$ Koch CG, Li L, Sessler DI, Figueroa P, Hoeltge GA, Mihaljevic T, Blackstone EH: Duration of red-cell storage and complications after cardiac surgery. N Engl J Med 2008;358:1229-1239.

-6 Basran S, Frumento RJ, Cohen A, Lee S, Du Y, Nishanian E, Kaplan HS, Stafford-Smith M, Bennett-Guerrero E: The association between duration of storage of transfused red blood cells and morbidity and mortality after reoperative cardiac surgery. Anesth Analg 2006;103:15-20.

7 Spinella PC, Sparrow RL, Hess JR, Norris PJ: Properties of stored red blood cells: understanding immune and vascular reactivity. Transfusion 2011; 51:894-900.

8 van de Watering L, for the Biomedical Excellence for Safer Transfusion (BEST) Collaborative: Pitfalls in the current published observational literature on the effects of red cell storage. Transfusion 2011;51:1847-1854.

9 Tinmouth A, Fergusson D, Yee IC, Hébert PC, for the ABLE Investigators and the Canadian Critical Care Trials Group: Clinical consequences of red cell storage in the critically ill. Transfusion 2006;46: 2014-2027.

10 Relevy H, Koshkaryev A, Manny N, Yedgar S, Barshtein G: Blood banking-induced alteration of red blood cell flow properties. Transfusion 2008;48: 136-146.

-11 Tsai AG, Cabrales P, Intaglietta M: Microvascular perfusion upon exchange transfusion with stored red blood cells in normovolemic anemic conditions. Transfusion 2004;44:1626-1634.

\12 Kaul DK, Koshkaryev A, Artmann G, Barshtein G, Yedgar S: Additive effect of red blood cell rigidity and adherence to endothelial cells in inducing vascular resistance. Am J Physiol Heart Circ Physiol 2008;295:H1788-H1793.

13 Högman CF, Meryman HT: Red blood cells intended for transfusion: Quality criteria revisited. Transfusion 2006;46:137-142.
14 Karger R, Lukow C, Kretschmer V: The influence of maintaining the correct whole blood-to-anticoagulant ratio during donation on the quality of leukoreduced whole blood. Transfusion 2011;51: 1486-1492.

15 Hardeman MR, Dobbe JGG, Ince C: The Laser-assisted Optical Rotational Cell Analyzer (LORCA) as red blood cell aggregometer. Clin Hemorheol Microcirc 2001;25:1-11.

16 Hardeman MR, Besselink GA, Ebbing I, de Korte D, Ince C, Verhoeven AJ: Laser-assisted optical rotational cell analyzer measurements reveal early changes in human RBC deformability induced by photodynamic treatment. Transfusion 2003;43: 1533-1537.

17 Dobbe JG, Hardeman MR: Red blood cell aggregation as measured with the LORCA. Int J Artif Organs 2006;29:641-642.

18 Altman DG: Practical Statistics for Medical Research, ed 1. Boca Raton, Chapman and Hall, 1991.

19 Henkelman S, Dijkstra-Tiekstra MJ, de WildtEggen J, Graaff R, Rakhorst G, van Oeveren W: Is red blood cell rheology preserved during routine blood bank storage? Transfusion 2010;50:941-948.

20 Berezina TL, Zaets SB, Morgan C, Spillert CR, Kamiyama M, Spolarics Z, Deitch EA, Machiedo $\mathrm{GW}$ : Influence of storage on red cell rheological properties. J Surg Res 2002;102:6-12.

21 Izzo P, Manicone A, Spagnuolo A, Lauta VM, Di Pasquale A DMD: Erythrocytes stored in CPD SAG-mannitol: Evaluation of their deformability. Clin Hemorheol Microcirc 1999;21:335-339.

22 Neu B, Meiselman HJ: Red blood cell aggregation; in Baskurt OK, Hardeman MR, Rampling MW, Meiselman HJ (eds): Handbook of Hemorheology and Hemodynamics. Amsterdam, IOS Press, 2007, pp 114-136.

23 Hovav T, Yedgar S, Manny N, Barshtein G: Alteration of red cell aggregability and shape during blood storage. Transfusion 1999;39:277-281.

24 Rampling MW, Meiselman HJ, Neu B, Baskurt OK: Influence of cell-specific factors on red blood cell aggregation. Biorheology 2004;41:91-112.

25 Zehnder L, Schulzki T, Goede JS, Hayes J, Reinhart WH: Erythrocyte storage in hypertonic (SAGM) or isotonic (PAGGSM) conservation medium: Influence on cell properties. Vox Sang 2008;95:280-287.

26 Hess JR: An update on solutions for red cell storage. Vox Sang 2006;91:13-19.

27 Högman CF, Meryman HT: Storage parameters affecting red blood cell survival and function after transfusion. Transfus Med Rev 1999;13:275-296.
8 Pries AR, Secomb TW: Microcirculatory network structures and models. Ann Biomed Eng 2000;28: 916-921.

29 Bennett-Guerrero E, Veldman TH, Doctor A, Telen MJ, Ortel TL, Reid TS, Mulherin MA, Zhu H, Buck RD, Califf RM, McMahon TJ: Evolution of adverse changes in stored RBCs. Proc Natl Acad Sci U S A 2007;104:17063-17068.

30 Raat NJ, Verhoeven AJ, Milk EG, Gouwerok CW, Verhaar R, Goedhart PT, de Korte D, Ince C: The effect of storage time of human red cells on intestinal microcirculatory oxygenation in a rat isovolemic exchange model. Crit Care Med 2005;33:39-45.

31 Carvalho FA, Maria AV, Braz Nogueira JM, Guerra J, Martins-Silva J, Saldanha C: The relation between the erythrocyte nitric oxide and hemorheological parameters. Clin Hemorheol Microcirc 2006;35:341-347.

32 Donadee C, Raat NJH, Kanias T, Tejero J, Lee JS, Kelley EE, Zhao X, Liu C, Reynolds H, Azarov I, Frizzell S, Meyer EM, Donnenberg AD, Qu L, Triulzi D, Kim-Shapiro DB, Gladwin MT: Nitric oxide scavenging by red blood cell microparticles and cell-free hemoglobin as a mechanism for the red cell storage lesion. Circulation 2011;124:465-476.

33 Moynihan R: Surrogates under scrutiny: fallible correlations, fatal consequences. BMJ 2011;343: d5160.

34 Abadi U, Butenero G, Kogan T, Ziv O, Paran H, Ellis MH: Prolonged blood storage does not effect survival in an animal model of hemorrhagic shock. Transfus Med Hemother 2011;38:272-276.

35 Natukunda B, Schonewille H, Smit Sibinga CT: Assessment of the clinical transfusion practice at a regional referral hospital in Uganda. Transfus Med 2010;20:134-139.

36 Laine E, Steadman R, Calhoun L, Blackall D, Levin P, Braunfeld M, Nourmand H, Neelakanta G, Ting L, Gornbein J, Busuttil R, Petz L: Comparison of RBCs and FFP with whole blood during liver transplant surgery. Transfusion 2003;43:322-327.

37 Holcomb JB, Spinella PC: Optimal use of blood in trauma patients. Biologicals 2010;38:72-77.

38 Chiang EP, Craig MG, Tao W: Whole blood transfusion in obstetric practice (letter). Transfus Med 2010;20:123-124.

39 Picker SM, Stürner SS, Oustianskaja L, Gathof BS: Leucodepletion leads to component-like storage stability of whole blood - suggesting its homologous use? Vox Sang 2004;87:173-181. 